\title{
Students Environmental Awareness of Ar Ridho Nature School Semarang
}

\author{
Agustina Prihatiningsih ${ }^{*}$ \\ Doctoral Program of Environmental Science, School of Postgraduate Studies, Diponegoro University, Semarang - Indonesia
}

\begin{abstract}
In order to meet the goal of environmental education, creating generation who are environmentally concerned and responsible, Ar Ridho Nature School Semarang (SAA), put the message of such education on their gardening subject. The subject has designed for grade 1 to 6 as the school commitment to build a civilization who are able to live in harmony with nature. The purpose of gardening is not only giving students environmental knowledge but also building environmental awareness and skill to preserve nature. Thus, this study aims at presenting environmental awareness among students of SAA and finding out whether there is a relationship between environmental knowledge and environmental awareness. The third grade of students were selected as participants since they were in the middle level of elementary education which has not applied 2013 Curricula (K13). A questionnaire survey was applied to 62 students face to face with considering the level of students for understanding the given questions. Descriptive statistics, ANOVA, and Pearson coefficient of correlation are the techniques used to analyze the data.
\end{abstract}

\section{Introduction}

Environment, one of the sustainable development pillars becoming ubiquitous topic discuss worldwide today. People has realized that the development of both economy and society should be in accordance with the environmental condition, thus the environmental protection is considered an integral part of the development process and cannot be isolated from it. In an attempt to conservation and preservation, Environmental Education has been applied to school curricula in every country, including Indonesia.

Environmental education according to UNESCO in Tbilisi Declaration 1978 is "a learning process that increases people's knowledge and awareness about the environment and associated challenges, develops the necessary skills and expertise to address the challenges, and fosters attitudes, motivations, and commitments to make informed decisions and take responsible action" [1].

In Indonesia, Environmental education has applied since 1996, after the two department ministries (environment department ministry and education and culture department ministry), signed Memorandum of Understanding (MoU) stated that the content of environment education should be integrated in school curricula.

Since then, many programs rolled out to schools' environment education. From the application of school subject Pendidikan Lingkungan Hidup to newest one, Adiwiyata School Program. In accordance with the spirit of sustainability, Sekolah Alam ArRidho (SAA) put gardening as the teaching method of environmental education. Gardening, from UNESCO (2012) is defined an alternative method in delivering Environmental Education since its activities provide students experience in real-life context.

Gardening is actually an amalgamation of the philosophies behind experiential education, ecological literacy and environmental awareness and agricultural literacy [2]. It involves teaching children through personal discovery in natural settings, where they learn ecological principles that govern all life, as well as develop a sense of connection with the land. Moreover, according gardening facilitate the children to open their minds to their natural existence, develop their sense of responsibility and of self-dependence, train them to respect the resources of the earth, teach them the obligations of citizenship, interest them sympathetically in the occupations of men, touch their relation to human life in general, and touch their imagination with the spiritual forces of the world [3]. Furthermore, gardening is expected to influence students environmental awareness. Environmental awareness (EA) is all about being conscious of the environment around us. EA is classified into two aspects: perception of environmental problems and behavioral inclination to protect the environment. The perception is the peoples should have knowledge of environment and their issues. The behavior inclination is to protect the environment includes two major aspects; firstly, the value of environmental protection in peoples mind which is indicated by the balance between environmental protection and economic development and also the willingness to pay for the protection of the environment; 
secondly, attitudes about participating in environmental protection [4].

In delivering EE for the elementary level, Maria Montessori, the founder of the Montessori method of child education stated that a garden could help children in developing their moral and appreciation in nature because the first education for children is the senses, then the education of the intellect [5]. She stated that nature can be a great basis for an introduction to the pleasures and later on the necessity for nurturing our living things [6]. Gardens can provide an environment in which students can learn to work with peers, teachers, parents and volunteers while growing plants and wild life [7]. Thus, supported gardening to become teaching method of EE. Teacher todays cannot get a child early enough to learn how to protect life and how to support the weak, but in gardening teachers teach how that damaged plants get a bandage to heal and weak ones a support [8]. Gardening then, expected to improve students' environmental awareness, as

The gardening effects has studied by many researchers. Waliczek and Zajicek studied the effects of an environmental curriculum, Project GREEN, on elementary and junior high students in Kansas and Texas. They found that participants' environmental attitudes improved after participating in the program [9]. Another study by Dirks and Orvis (2005) found that 3rd grade participants in the Junior Master Gardener Program increased in environmental knowledge and attitudes compared to non-participants [10]. In brief, schools with a garden demonstrated more positive gains than those without [11].

Thus, the purpose of the study is to examine the influence of students environmental knowledge from gardening activities with environmental awareness.

\section{Material and Methodology}

This paper investigated the extent of students' environmental awareness after taking gardening activities.

\subsection{Sample}

The study sample included 63 students of grade III Sekolah Alam Ar Ridho Semarang in the first semester of academic year 2016-2017.

\subsection{Measuring Tools}

In this study, the five-point Likert-type consists five possible responses: Disagree (1), Strongly disagree (2), Don't Know/ Don't Care (3), Agree (4) and Strongly Agree (5) Environmental Awareness towards Plants Questionnaire adapted and modified from Childs (2011) was used to assess students environmental awareness. The questionnaire consists of 21 questions. The questionnaire's reliability was a Cronbach alpha of .949. the data obtained from the questionnaire were analyzed by using the descriptive statistics, ANOVA, and Pearson coefficient of correlation in SPSS 21 for windows statistical software.

\section{Research Finding}

\subsection{Descriptive Statistics, ANOVA and Pearson coefficient of correlation}

The study included total of 62 students grade III in three parallel classes. Of the 24 students were female $(38,7 \%)$ and 38 students were male $(61,3 \%)$.

In the Table 1 below, Cronbach Alpha produced in each variable was $<0.60$. Whereas, Corrected Item Total Correlation showed in each variable was $<0,30$. It means that the variables used were reliable.

Table 1. Item-Total Statistics

\begin{tabular}{|l|r|r|r|r|}
\hline & $\begin{array}{c}\text { Scale } \\
\text { Mean if } \\
\text { Item } \\
\text { Deleted }\end{array}$ & $\begin{array}{c}\text { Scale } \\
\text { Variance if } \\
\text { Item } \\
\text { Deleted }\end{array}$ & $\begin{array}{c}\text { Corrected } \\
\text { Item-Total } \\
\text { Correla- } \\
\text { tion }\end{array}$ & $\begin{array}{c}\text { Cronbach' } \\
\text { S Alpha if } \\
\text { Item } \\
\text { Deleted }\end{array}$ \\
\hline q1 & 67,81 & 197,700 &, 847 &, 944 \\
q2 & 67,84 & 197,580 &, 717 &, 946 \\
q3 & 67,84 & 197,580 &, 717 &, 946 \\
q4 & 68,06 & 196,553 &, 699 &, 946 \\
q5 & 67,35 & 206,921 &, 483 &, 949 \\
q6 & 66,85 & 208,585 &, 565 &, 948 \\
q7 & 67,00 & 214,656 &, 395 &, 950 \\
q8 & 67,76 & 203,465 &, 610 &, 947 \\
q9 & 67,35 & 204,397 &, 696 &, 946 \\
q10 & 67,40 & 204,835 &, 634 &, 947 \\
q11 & 67,79 & 201,283 &, 659 &, 947 \\
q12 & 68,10 & 202,056 &, 653 &, 947 \\
q13 & 68,16 & 200,859 &, 697 &, 946 \\
q14 & 68,19 & 198,027 &, 698 &, 946 \\
q15 & 67,81 & 197,700 &, 847 &, 944 \\
q16 & 67,69 & 200,905 &, 726 &, 946 \\
q17 & 67,69 & 200,905 &, 726 &, 946 \\
q18 & 68,06 & 196,553 &, 699 &, 946 \\
q19 & 68,39 & 205,290 &, 501 &, 949 \\
q20 & 67,71 & 199,718 &, 732 &, 946 \\
q21 & 67,71 & 199,718 &, 732 &, 946 \\
\hline
\end{tabular}

Table 2. Model Summary ${ }^{\mathrm{b}}$

\begin{tabular}{|l|r|r|r|}
\hline Model & \multicolumn{1}{|c|}{ R } & R Square & \multicolumn{2}{|c|}{$\begin{array}{c}\text { Adjusted R } \\
\text { Square }\end{array}$} \\
\hline 1 &, $726^{\mathrm{a}}$ &, 527 &, 519 \\
\hline
\end{tabular}

a. Predictors: (Constant), Environment Knowledge (x1)

b. Dependent Variable: Environment Awareness (x2)

Determinant coefficients value showed in Table 2, on Adjusted R square column wass0,519 means 51.9\% the change of Environmental Awareness (EA) variable determined by the change of Environmental Knowledge 
(EK) variable, while the rest of $43,5 \%$ determined by other variables which did not explained in this study.

\subsection{Observation}

The study has conducted for six months (from July to December 2016. The researcher observed the gardening activies in grade III in three classes. Teachers in every class were asked to observed students' environmental awareness during the six months gardening activities. The result from the observation showed students who were not interested in gardening performed less awareness toward plants than the students who enjoyed gardening.

\subsection{Interview}

In the study, the findings about the interviews with two students representatives in every class confirmed the observation findings. During the interviews, they were asked about the gardening activities they experienced. Some examples of the interview findings were presented below:

Interviewer: What did you learn from gardening?

All of the 6 students answered the questions similarly. The explained what they get for gardening.

"I learnt how plant vegetables, from seeding to taking care of them and finally how to identify vegetables which are ready to harvest and the teacher used to remind us the gardening rules, what we shoul do and should not do in the garden"

Interviewer: Are you enjoy gardening activities? Why or why not?

The responds of this questions were varied. Four students answered positively, while two of them considered gardening as an boring activities.

"I did enjoy gardening, I love taking care of plants and the most expecting moment for us was harvesting."

While another students answered:

"I didn't like gardening, the activities were so monotonous and I had dirty." (Students 1)

"I didn't like gardening, I felt bored with the activities, I do hope that the teacher would create the interesting ones." (Students 2)

Interviewer: Do you have any plan to caring for plants in your spare time?

As the four students responsed positively for the previous question, the answer of the four students were the same.

"Of course, I would. In fact, I really love taking care of plants. they gave us oxygen, food and aesthetic." (Students 3)

Interviewer: Do you think gardening effects your awareness towards plants?

Four of students answered "yes".
" Of course, the gardening activities triggered our sense of belonging to plants and I would feel sad if we didn't take care of them". (Students 4)

While another students added the answer, " I would feel so mad if I saw someone step on the plants and destroyed them."

The interview conducted not only with sudents but also teachers. Teachers were asked about the gardening curriculum.

Interviewer: How do you find this gardening curriculum?

"I think we do need a revision, the exist curriculum have not covered the complete materials and activities variation."'(Teacher 1)

"Ya... the activities has not been designed specifically, as the result, each teacher count on their knowledge and ability of gardening." (Teacher 2)

\section{Conclusion}

The study found that Environment Knowledge (EK), that the students got from gardening activities influenced $51,9 \%$ of students Environmental Awareness (EA). The result of both observation and interview confirmed this result. Most of the students enjoyed the gardening activities, which the rest didn't. From the interview with both students and teacher determined that gardening activities had effected on students environmental awareness. Furthermore, in order to develop the effects of gardening in Ar Ridho Nature School the newest revision of gardening curriculum is needed.

\section{References}

1. Tbilisi Declaration (Final report of the International Conference of EE:Tbilisi,(1978)

2. Subramaniam, GBL in Basic Ed, (2002).

3. L.H. Bailey, THSI ., (1990)

4. X. Xietal, X., Lihong, and D. Xueming, PEA in China, (1998)

5. M. Montessori, The absorbent mind, (1912)

6. M. Montessori, The Montessori method, (1964)

7. C.D. Klemmer, T.M. Waliczek, J.M. Zajicek.. GM:. HorT Tech, 15(3):448-452, (2005)

8. K. Green, Encouraging nurturing behavior of two to seven year olds by introducing plants and flowers, (1994)

9. S.M. Skelly, and J.M. Zajicek.. HortTech. 8(4):579583, (1998)

10. A.E. Dirks and K. Orvis,. HortTech, 15(3):443-447, (2005)

11. A.W. Fleener,, Masters Thesis, (2008) 